\title{
Customer's Attitude Towards Mobile Advertising in Bangladesh
}

\author{
Sheikh Majedul Huq ${ }^{1}$, S. M. Shahedul Alam ${ }^{1}$, Md. Nekmahmud ${ }^{1}$, Mst. Shuly Aktar ${ }^{1}$, \\ S. M. Shamiul Alam ${ }^{2}$ \\ ${ }^{1}$ Department of Marketing, Faculty of Business Studies, Begum Rokeya University, Rangpur, Bangladesh \\ ${ }^{2}$ Farm Power and Machinery, Bangladesh Agricultural University, Mymensingh, Bangladesh
}

\section{Email address:}

huqsajib@yahoo.com (S. M. Huq), shahedul1992@gmail.com (S. M. S. Alam), argonmkt@yahoo.com (Md. Nekmahmud), sheulymajedul@gmail.com (Mst. S. Aktar), s_saikot@yahoo.com (S. M. S. Alam)

\section{To cite this article:}

Sheikh Majedul Huq, S. M. Shahedul Alam, Md. Nekmahmud, Mst. Shuly Aktar, S. M. Shamiul Alam. Customer's Attitude Towards Mobile Advertising in Bangladesh. International Journal of Business and Economics Research. Vol. 4, No. 6, 2015, pp. 281-292.

doi: $10.11648 /$ j.ijber.20150406.13

\begin{abstract}
In the age of information communication technology (ICT) uses of mobile phone or cell phone is increasing and business environment of Bangladesh is becoming more competitive day by day. Most of the companies strive to maximize their sales volume and use advertisements to promote their products and services. The main objective of the study is to examine the customer's attitude towards mobile advertising in Bangladesh. Through which marketers can scan the real scenario about the customer's attitude towards the mobile advertising. The study, descriptive in nature, has been conducted based on primary and secondary data. A conceptual framework has been designed to conduct the research. That is hypothesized on the five independent variables, these are: entertainment, informativeness, irritation, credibility and incentive have influenced on attitude towards mobile advertising. The study has been conducted among 130 respondents over fourteen (14) years old in Bangladesh, who own a cell phone. The survey questionnaire has been included 21 attitude measurement questions designed under seven (7) points semantic differential scale. The collected data have been analyzed by using factor analysis and multiple regression analysis through the SPSS 20.0 version. The study also shows that companies taking permission from only $17 \%$ of respondents sending mobile advertising. Most of the customers would like to receive mobile advertising in the morning and night. The factor analysis of the study also divided the predictors into six different factors those can be used for the further study. Customer's attitude towards the mobile advertising has explained $69.8 \%$ by the independent variables were entertained, informativeness, credibility and incentive have positive and irritation has negative influence on consumer attitude. It can help to take proper business decisions and making suitable competitive strategies about effective business communication and advertisement which can ensure its long term sustainable economic development in the competitive business world.
\end{abstract}

Keywords: Mobile Advertising (MA), Customer Attitude, Entertainment, Informativeness, Credibility, Irritation, Incentive, Bangladesh

\section{Introduction}

In the era of globalization the necessity of effective communication is very indispensable. We know that promotional tools help to create information utility. To know the appropriate information is the basic right of any consumer. Mobile phone or Cell phone is the most lucrative weapon that helps to keep in aware about the changes of information. Mobile advertising is raising issues in the 3rd world country like Bangladesh.
The world has perceived enormous and rapid technological developments influencing the advertising style of different proactive companies during the recent years. Many companies strive to maximize their sales volume and use advertisement to promote their products and services. Generally, traditional advertising has been applied by most of the organizations around the world which is still playing an important role as a popular advertising technique. Most of the proactive company works for orchestrating a closer harmony between their advertising messages and mobile communication technology. 
The mobile phone is not only a personal device used to stay connected with friends and family, but also an extension of their personality and individuality (Grant \& Donohoe, 2007; Sultan \& Rohm, 2005) [20] [44]. Now a day's mobile phone is used in marketing activities that means Mobile Marketing. Mobile marketing is actually the advertisement through mobile phones provide information, knowledge and awareness about your brand to the people and also capturing your target market through the mobile advertisement (Saeed et al., 2013) [39]. Mobile marketing is a kind of wireless medium which provides necessary information on time with location specifics in more customized ways to consumers promoting the advantage of products and services. Mobile advertising (MA) is a technologically advanced and innovative way to communicate with the consumers (Barnes \& Scornavacca, 2004) [5]. According to The Mobile Economy Report 2015, the mobile industry continues to scale rapidly with a total of 3.6 billion unique mobile subscribers at the end of 2014. Half of the world's population now has a mobile subscription up from just one in five 10 years ago. An additional one billion subscribers are predicted by the year 2020, taking the global penetration rate to approximately $60 \%$. There were 7.1 billion global SIM connections at the end of 2014, and a further 243 million machine-to-machine (M2M) connections. As per the information of Bangladesh Telecommunication Regulatory Commission (BTRC), the total number of mobile phone subscriptions has reached 124.705 million at the end of April 2015. There are six (6) mobile phone operators in Bangladesh, operating under the names of Grameenphone, Airtel, Banglalink, Robi, Citycell and TeleTalk. The number of mobile phone subscribers in Bangladesh as of April 2015 was 124.705 million, having risen from the February 2009 figure of 45.21 million. Consumer market, business market, institutional market even People's Republic of Bangladesh is communicating with their target audience to change customer's attitude towards them through mobile phone SMS, MMS, voice, SMS, voice call, video call, etc. Now a days cell phone is becoming more popular and user friendly device due to its convenient using and availability of low cost to communicate with all classes of people. The political parties and person are usually trying to build strong positive image in favor of them through the mobile advertising. Mass people also accepted it positively. Various types of company like GP, Bata, Robbi, Apex, Lotto, Brothers furniture, Bank, Insurance, etc. are trying to communicate with their target customers to inform, peruse, and provides a new offer or sales promotion through the mobile advertising in Bangladesh which is very selective and receiver will get the message or keep record it certainty.

At present, Bangladesh Government is ensuring Digital Bangladesh delivery of Government services to the citizens of Bangladesh through maximum use of technology, with the ultimate goal being the overall improvement of the daily lifestyle of general people. Mobile Advertising has emphasized the use of information technology to achieve Bangladesh's economic development goals. So Mobile advertising helps to contribute in Bangladesh to be digitized.
Most of the companies have started sending promotional messages in the form of SMS to people. Mobile marketing is the cheapest means of advertisements (Tedeschi, 2007) [45]. Sending SMS is very cost-effective and it is because of this reason companies are using the full benefits of mobile marketing (Zanton, 1981) [51]. Mobile marketing presents an opportunity for consumers, operators, and governments to benefit from increased mobile adoption by providing alternative capitalization methods for obtaining mobile phones, subscriptions, and services. It is important to understand consumer's attitudes toward mobile advertising in the hopes of utilizing mobile advertising campaigns to supplement mobile usage fees and startup costs (Chowdhury et al., 2010) [13]. Entertainment, credibility, irritation and informativeness are the significant factors affecting respondents' attitudes toward mobile advertising (Tsang et al., 2004) [46].

Mobiles are more user-friendly than that of the computers. As soon as people get messages on their cell phones they instantly check their messages. If these messages are in favor of them, then they would reply the senders or if these are found to be useless they would instantly delete them. So, it has come to knowledge that promotional messages by means of mobiles reach to people faster than that of internet marketing. Since mobile marketing saves much time, it has won the favor of many companies which are into retail sector (Rip \& Kemp, 1998) [37].

Companies are highly requested to take up mobile marketing as most of the small companies have already taken up this process of marketing. The advantages of mobile marketing cannot be expressed in a few words. Companies through these means of mobile marketing can make people read their promotional messages (Scharl et al., 2005) [40]. The studies of customer's attitudes toward mobile advertising were conducted in many countries, but there has been no similar research in Bangladesh. Additionally, because of rapid changes in technology, most of the research has focused on SMS advertising and does not include new types of mobile advertising such as mobile web banner or mobile application advertising (Carroll et al., 2007) [11].

The main objective of the study is to investigate the customer's attitude towards mobile advertising in Bangladesh. Researchers try to find out customers' attitude based on following factors i.e. entertainment, information, credibility, irritation and incentives. Through which marketers can scan the real scenario about the customers' attitude towards the mobile advertising. It can make capable enough to take proper decision about effective communication and advertisement which can ensure its long term sustainability in the competitive business world.

\section{Review of Relevant Literature}

\subsection{Attitude}

Kotler (2010) stated that Attitude of a person defines his/her favorable or unfavorable assessments, expressive feelings and diverse actions predisposition towards some 
objects or ideas [28]. An Attitude is a learned predisposition behaves in a consistently favorable or unfavorable manner with respect to a given objective (Schiffman et al., 2008) [41]

\subsection{Mobile Advertising}

The promotion of goods and services through interactive digital media such as wireless phones, cellular phones, gps, pda's and mobile portals is called advertisement via mobile phones (Xu, D. J. 2006) [49].

According to Investopedia defines "Mobile advertising is a method of advertising that appears on mobile devices such as smart phones, tablets or PDAs that have wireless connections. Advertising can take place as text ads via SMS, or banner advertisements that appear embedded in mobile website, in downloaded apps or in mobile games".

\subsection{Company's Attitude Towards Mobile Advertising}

Company's attitude towards mobile advertising to attract more customers, brands suggests that the ad agency design advertising campaigns. The mobile advertising network has a responsibility as a distributor and an intermediary to share the advertisement to audiences through mobile web sites or applications (Le et al., 2014) [29]. Mobile advertisement is a unique channel through which marketers can send customized message to consumers according to their attributes. Managing long term relationships with customers is the essence of marketing management and mobile advertisement helps to achieve these goals (Haider, 2012) [23]. The mobile advertising ecosystem has many players: brands, advertising agencies, advertising networks, publishers and users (Bauer et al., 2005; Barnes \& Scornavacca, 2008) [7] [6]. According to Haghirian and Inoue (2006) the world's leading information technology research and advisory company, mobile web display, in app display and search/maps are the three types of mobile advertising that have the highest revenue [22]. In addition, (Mobithinking, 2013) predicts that the revenue of these types will continue to grow in the future [33].

\subsection{Customers'Attitude Towards Mobile Advertising}

Customers' attitude towards mobile advertising has a significant correlation between favorable attitudes toward advertising and respondents' rating of specific advertisements as being annoying, likeable, enjoyable etc. has been observed (Bauer \& Greyser, 1968) [8]. A consumer's attitude for an advertisement has an essential control on advertising effectiveness, buying intentions and brand attitudes (MacKenzie \& Lutz, 1989) [31]. Research (e.g. Scharl et al., 2005; Tsang et al., 2004) drawing on the Theory of Reasoned Action [40] [46].

Ajzen and Fishbein (1980) found positive relationships between attitudes, intention, and behavior associated with mobile advertising [2].

Le and Nguyen (2014) the research works on attitudes toward mobile advertising: a study of mobile web display and mobile app display advertisement. This study has investigated that many users do not have positive feelings toward advertising; they cannot ignore the importance of mobile advertising. If mobile advertisers can present credibility and entertainment in their advertisements, consumers are willing to view the ads and be influenced to buy products and services [29].

Saeed et al. (2013) have found that the effectiveness of the mobile advertisement on the consumer behavior, that's how different people would act or what would be their response upon receiving the mobile advertisement. They also observed that the consumers generally have a negative attitude toward the mobile advertisement unless the advertisers had specifically taken the consent of the consumer [39].

ALhrezat (2013) researched on factors affecting consumer's attitudes toward mobile marketing and focuses on four independent variables to achieve the objective of the study, which are: Customer satisfaction for the content of the advertising message, Customer trust of the content of the advertising message, the Value and the utility of the offers that are provided by the advertising message, brand of the products that are offered by the advertising message. All this independent variable had a significant effect on Saudi consumer's attitudes toward acceptance mobile marketing [3].

Zabadi et al. (2012) have studied that Consumer Attitudes toward SMS Advertising among Jordanian Users. They identified that consumer' perceptions of the entertainment value, Informativeness and credibility of SMS advertisements are positively correlated with consumers' overall attitudes towards SMS advertisements. Attitude toward advertising via mobile devices strongly depends on message Characteristics [50].

Haider (2012) conducted a study to know prioritization of factors affecting consumer attitude towards mobile advertisement: a study of Pakistani youth and he scrutinize the attitudes of customers of the Sargodha city (Pakistan) towards mobile advertising applications. He initiates and launch mobile message advertising applications as companies knows the importance of this channel in the close to future and when companies devote more in adopting and mounting mobile media as a channel of communication [23].

Rohm et al. (2012) stated that three factors perceived usefulness; consumer innovativeness and personal attachment have a major influence on consumers' attitude towards mobile marketing. The study concluded that mobile marketing is providing an innovative platform to communicate with the consumers with new and profitable opportunities for the firms to develop or alter consumer attitudes towards a brand by the virtue of value added content [38].

Zabadi et al. (2012) researched on consumer attitudes towards SMS advertising among Jordanian users and examined the experiences of consumers with SMS advertising via mobile phones and variables influencing it. The results of the study indicated that consumer attitude towards advertising through mobile phones is strongly dependent on messages attributed. Therefore, messaged attributes must be defined carefully. It also described that 
advertising value and advertising message content have a long lasting impact on attitude formation towards mobile advertising through mobile phones [50].

Punyatoya and Durgesh (2011) found that message credibility, consumer perception of message customization, message content, and consumer's ability to use mobile phone positively influence their attitude towards acceptance of mobile advertising. But consumer inertia negatively influences consumer mobile advertising acceptance [35].

Tsang et al. (2004) studied the consumers' attitude towards mobile phone advertising and its relationship with overall consumer behavior. This research described entertainment, informativeness and credibility has a positive impact on consumer attitude towards mobile advertisement while irritation negatively influence consumer advertising attitude [46].

Bose et al. (2010) the research attempted of SMS advertising and its prospects in Bangladesh and they examine whether SMS advertising can be an effective medium of advertising in Bangladesh. Consumers have shown a positive attitude in accepting SMS ads via their mobile phones. The study will contribute significantly regarding the policy making of both the business professionals as well as advertising professionals in selecting and establishing the proper advertising methods as well as medium in future for operating in the best possible way in the country [9].

Luxton et al. (2009) identified that the key drivers of consumer attitudes toward mobile marketing are posited as perceived entertainment, credibility, reward, technological familiarity, and message frequency. Consumer shopping orientation is posited to act as a mediator, and age, gender and education also have an influence [30].

Chowdhury et al. (2006) conducted research in Bangladesh that only perceived credibility has a positive impact on consumer attitude while other factors have insignificant correlation with the consumer attitude towards mobile advertising [13]. These studies show that researches take different factors and conclude different results based on five selected factors. Present studies motivated us to capture previous researchers pertaining factors in this research.

\section{Research Model}

\subsection{Conceptual Research Framework}

H1

\begin{tabular}{|c|c|c|}
\hline Entertainment & & 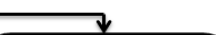 \\
\hline Informativeness & & \\
\hline Irritation & H3 & Attitude towards \\
\hline Credibility & $\mathrm{H} 4$ & \\
\hline Incentive & H5 & $\pi$ \\
\hline $\begin{array}{l}\text { Independent } \\
\text { Variables }\end{array}$ & & $\begin{array}{c}\text { Dependent } \\
\text { Variable }\end{array}$ \\
\hline
\end{tabular}

Figure 1. Conceptual framework of the study.
Based on the previous literature review our research work developed a conceptual framework of customer's Attitude towards mobile advertising in Bangladesh. Figure 1, represents the conceptual framework of the research. The framework hypothesizes the five Independent Variables, these are entertainment, informationess, irritation, credibility and Incentive have an influence on customer's attitude towards mobile advertising.

\subsection{Hypotheses Development}

\subsubsection{Entertainment}

Entertainment can be defined as "the ability to fulfill an audience's need for escapism, diversion, aesthetic enjoyment, or emotional enjoyment" (Ducoffe, 1996) [17]. The mobile phone has become an important media and entertainment platform. The stance of cheerfulness and pleasure in individuals is called entertainment. People's feeling of enjoyment associated with advertisements plays a vital role in the overall value of the advertisement (Shavitt et al., 1998) [42]. So it is necessary that the message is concise and funny, and thus immediately captures the consumers' attention (Kalakota \& Robinson, 2002) [25]. Entertainment element in advertising can fulfill consumers' needs for aesthetic enjoyment and emotional release (Ducoffe, 1996) [17]. Entertainment is a crucial factor for mobile marketing. It is essential that the message is concise and funny, and thus immediately captures consumers' attention (Katterbach, 2002) [26]. The mobile phone has become a prominent media and entertainment platform. Entertainment services can add value for the customer and increase customer loyalty (Haghirian \& Dickinger, 2004) [21].

Most of the consumers like children and people of young age like the factor of entertainment in any type of ads but the actual consumers are the adults and old people and they mostly do not like the factor of entertainment (Saeed et al., 2013) [39] Therefore, hedonic pleasure (perceived entertainment value) had a positive effect on attitudes towards advertising, the perceived entertainment value of mobile advertisements will be one of the important factor affecting consumers' attitudes toward advertising (Bauer et al., 2005) [7]. Based on the aforementioned discussion, the following hypothesis is developed.

H1: Entertainment of advertising has a positive significant influence on customer's attitude towards mobile advertising in Bangladesh.

\subsubsection{Informativeness}

Informativeness can be defined as "the ability of advertising to inform consumers of product alternatives so that purchases yielding the greatest possible satisfaction can be made" (Ducoffe, 1996) [17]. In formativeness means how much information is provided to the consumers. It is necessary that complete and comprehensive information must be provided to the consumers (Saeed et al., 2013) [39].

One of the advertising goals is to inform the audience about new products or new features of existing products, also make the audience aware of changes in products' price 
(Kotler \& Keller, 2006) [27]. In advertisement information play a significant role, it has the ability to convey beneficial information (Daugherty et al., 2008) [14] and it also provides utilitarian offer and practical information (Okazaki, 2005) [34]. In formativeness can be interrupted as the ability of advertising to deliver information to customers in order to satisfy their needs. The Optimum Stimulation Level Theory states that people aspire to accomplish a certain degree of stimulation and collect information with intrinsic motivation (Hoffman, 1996) [24] informativeness of the advertising is strongly related to the attitude toward the advertising when it is transferred via traditional media (Ducoffe, 1995) [18]. Informativeness affects consumers 'attitudes toward mobile advertising in general. So it can be concluded that informativeness of mobile advertising message positively influences attitude (Tsang et al., 2004) [46]. Based on the aforementioned discussion, the following hypothesis is developed.

$\mathrm{H} 2$ : Informativeness of advertising has a positive significant influence on customer's attitude towards mobile advertising in Bangladesh.

\subsubsection{Irritation}

In the context of advertising defines irritation as: "When advertising employs tactics that annoy, offend, insult, or are overly manipulative consumers are likely to perceive it as unwanted and irritating influence (Ducoffe, 1996) [17]. Mobile advertising may provide an array of information that confuses the recipient and can be distracting and overwhelming the consumer with information (Stewart \& Pavlou, 2002) [43]. Other characteristics of irritation in mobile advertising include surplus messages that are annoying to consumer attitude (Dickinger et. al., 2004) [16]. Irritation in advertising can be termed as an advertisement that creates annoyance, unhappiness, and brief intolerance (Aaker \& Bruzzone, 1985) [1]. Irritation comprises the only negative dimension of consumer attitudes towards mobile advertising (Altuna et al., 2009) [4]. The relationship between consumers' perceptions of the irritation of an advertisement and consumers' attitudes towards an advertisement is theoretically supported by the attitude model developed by (Brackett \& Carrs, 2001) [10]. Consumer perceptions of the irritation of SMS advertisements are negatively correlated with consumer attitudes towards SMS advertisements (Tsang et al., 2004) [46].

The survey of Bauer and Greyser (1968) conducted on American consumer concluded that consumer shows negative response to advertisement that or annoyance or cause the irritation [8].

Consumers' perceptions of the irritating aspects of SMS advertisements are negatively correlated with consumers' attitudes towards SMS advertisements (Zabadi et al., 2012) [50]. Due to the comparatively low cost of advertising via short messaging service and multimedia messaging service, companies send the collective short message without taking care of privacy or consumer concern. As a result of this, most people are irritated and disturbed because of these wrong marketing tactics (Rittippant et. al., 2009) [37]. Based on the aforementioned discussion, the following hypothesis is developed.

H3: Irritation of advertising has a significant negative influence on customer's attitude towards mobile advertising in Bangladesh.

\subsubsection{Credibility}

Advertising credibility is the consumers' perception of the truthfulness and believability of advertising in general (Stewart \& Pavlou, 2002) [43]. Advertising credibility is "consumers' perception of the truthfulness and believability of advertising in general" (Mackenzie \& Lutz, 1989) [31]. In Wiedemann and Pousttchi's study (2008) almost 70\% of the 44 experts stated that this mobile form of interpersonal communication is an important characteristic of a mobile marketing campaign [48]. The credibility of an advertisement is influenced by different factors, especially by the company's credibility (Goldsmith et al., 2000) [19]. Perceived Credibility distinct as, "The believability of consumers about the advertisement that offerings of a company will satisfy their needs \& wants and also has a direct positive effect on respondent's attitude towards any ad or brand" (Choi \& Rifon, 2002) [12].

Research conducted by various researchers has identified that there is a positive correlation between consumer perceptions of the credibility of an advertisement and consumer attitudes towards the advertisement (Brackett, 2001) [10]. Based on the aforementioned discussion, the following hypothesis is developed.

H4: Credibility of advertising has a positive significant influence on customer's attitude towards mobile advertising in Bangladesh.

\subsubsection{Incentive}

Incentive is something that tends to incite to action or greater effort, as a reward offered for increased productivity. It also means the uses of motivational tools such as discount, coupons, competitions, games, premiums, special pricing, to promote the sales of products and services. Respondents are having a positive attitude towards mobile advertisements and towards the offers that firm gives to the respondents for shopping like coupons \& discount (Dawar \& Kothari, 2013) [15]. Information is thus considered a very valuable incentive in mobile marketing, because recipients react very positively to advertising transferring incentives (Varshney, 2003) [47]. Incentive-based advertising affords specific financial rewards to individuals who agree to receive promotions and campaigns. For example, mobile phone companies may incentive customers with free connection time for listening to voice advertisements. Both permissions-based and incentivebased advertising appliances are feasible for mobile advertising because the wireless technology makes it possible to identify individual users (Tsang et al., 2004) [46]. Based on the aforementioned discussion, the following hypothesis is developed.

H5: Incentive of advertising has a positive significant 
influence on customer's attitude towards mobile advertising in Bangladesh.

\section{Methodology of the Study}

The selected population for the study includes all consumers, over fourteen (14) years old in Bangladesh, who own a cell phone. The respondent has past experienced to receive a mobile advertisement from companies or organizations which promote their products or services in this way. The random sampling method is used to select respondents from five (5) divisions likes Dhaka, Chittagong, Rangpur, Rajshahi and Khulna out of eight (8) divisions in Bangladesh. Primary data were collected over a four months period during the January to April, 2015.

The questionnaires were distributed directly to the respondents as a study sample. In this study, researcher distributes 180 questionnaires to respondent for measuring the customer's attitude towards the mobile advertising. Among them, 150 respondents returned the filled up questionnaires. Due to respondent's inability, unconsciousness and excessive missing values 20 questionnaires were dropped. So, finally the size of the sample stands at 130 (One Hundred Thirty).

This study is descriptive in nature. It is conducted based on primary and secondary data. Rendering the purpose of the study, field survey method is used to collect primary data by taking direct interviews through the questionnaire. The survey questionnaire is included 21 attitude measurement question, including some demographic questions to make better understanding about study outcomes. Here seven (7) points semantic differential scale was used to design attitude measurement related questions. Where, $1=$ strongly disagree, $2=$ disagree, $3=$ somewhat disagree, $4=$ neither agree nor disagree (neutral), $5=$ somewhat agree, $6=$ agree and $7=$ strongly agree. Secondary data was collected from previous articles and different related publications.

The collected data are analyzed by various statistical tools and techniques including frequency distribution, reliability test (Cronbach $\alpha$ ) and factor analysis (principal component analysis with Varimax rotation) and multiple regression analysis through the data processing software SPSS 20.0 version.

\section{Data Analysis and Findings of the Study}

Table 1. Summary of Socio-Demographic profile of Respondents.

\begin{tabular}{|c|c|c|c|}
\hline \multicolumn{2}{|c|}{ Demographic Variables } & \multirow{2}{*}{$\begin{array}{l}\text { Frequency } \\
82\end{array}$} & \multirow{2}{*}{$\begin{array}{l}\text { Percentage } \\
(\%) \text { of } \\
\text { Respondents } \\
63.1\end{array}$} \\
\hline \multirow{2}{*}{ Gender } & Male & & \\
\hline & Female & 48 & 36.9 \\
\hline \multirow{3}{*}{ Area of Living } & Urban & 96 & 73.8 \\
\hline & Rural & 34 & 26.2 \\
\hline & Less than 20 years & 29 & 22.3 \\
\hline \multirow{3}{*}{$\begin{array}{l}\text { Age of the } \\
\text { Respondent }\end{array}$} & $21-30$ years & 50 & 38.5 \\
\hline & $31-40$ years & 30 & 23.1 \\
\hline & More than 40 & 21 & 16.2 \\
\hline \multirow{3}{*}{ Marital Status } & Unmarried & 58 & 44.6 \\
\hline & Married & 72 & 55.4 \\
\hline & Primary education & 13 & 10.0 \\
\hline \multirow{4}{*}{$\begin{array}{l}\text { Level of } \\
\text { Education }\end{array}$} & Secondary education & 64 & 49.2 \\
\hline & Higher education & 47 & 36.2 \\
\hline & Others & 6 & 4.6 \\
\hline & Service holder & 46 & 35.4 \\
\hline \multirow{5}{*}{$\begin{array}{l}\text { Occupational } \\
\text { Status }\end{array}$} & Business & 23 & 17.7 \\
\hline & Student & 29 & 22.3 \\
\hline & Housewife & 16 & 12.3 \\
\hline & Others & 16 & 12.3 \\
\hline & $0-5000$ & 16 & 12.3 \\
\hline \multirow{5}{*}{$\begin{array}{l}\text { Average } \\
\text { Monthly } \\
\text { Income (In } \\
\text { Taka) }\end{array}$} & $5000-10000$ & 19 & 14.9 \\
\hline & $10000-20000$ & 48 & 36.9 \\
\hline & $20000-30000$ & 37 & 28.5 \\
\hline & $30000-40000$ & 10 & 7.7 \\
\hline & Total (Respondents) & 130 & 100 \\
\hline
\end{tabular}

Table 2. Frequency Distribution of Behavioral Characteristics.

\begin{tabular}{|c|c|c|c|}
\hline Variables & & Frequency & Percentage (\%) of Respondents \\
\hline \multirow{2}{*}{$\begin{array}{l}\text { Most of the mobile companies communicate MA } \\
\text { to me after they got permission from me }\end{array}$} & Yes & 23 & 17.7 \\
\hline & No & 107 & 82.3 \\
\hline \multirow{2}{*}{$\begin{array}{l}\text { Companies always send me MA which provided } \\
\text { discounts or coupons }\end{array}$} & Yes & 69 & 53.1 \\
\hline & No & 50 & 38.5 \\
\hline \multirow{2}{*}{ I have a high involvement with MA. } & Yes & 67 & 51.5 \\
\hline & No & 63 & 48.5 \\
\hline I often use MA for shopping. & No & 100 & 76.9 \\
\hline \multirow{4}{*}{$\begin{array}{l}\text { In which part of the day, you would like to } \\
\text { receive MA. }\end{array}$} & In the Morning & 41 & 31.5 \\
\hline & At Noon & 26 & 20.0 \\
\hline & At Afternoon & 24 & 18.5 \\
\hline & At Night & 39 & 30.0 \\
\hline \multirow{4}{*}{ I am willing to receive amount of MA. } & Less than one or one message in a day & 23 & 17.7 \\
\hline & Two messages in a day & 19 & 14.6 \\
\hline & Three messages in a day & 55 & 42.3 \\
\hline & More than four or four messages in a day & 33 & 25.4 \\
\hline
\end{tabular}


The Table 1, summary of respondents' demographic statistics, shows that $63.1 \%(\mathrm{n}=82)$ male and $36.9 \%(\mathrm{n}=48)$ female belong to less than 20 years $(n=29) 22.3 \%, 21-30$ years $(n=50) 38.5 \%, 31-40$ years $(n=30) 23.1 \%$ and more than $40(\mathrm{n}=21) 16.2 \%$. Here, $(61 \%)$ respondents of this study having secondary and higher education. The analysis also shows that $35.4 \%$ respondents were service holder and $22.3 \%$ belong to students and rests on them were business person, housewife and other professionals.

As per the Table 2, the study also shows that companies communicating with their consumers through mobile phone and take permissions from only $17 \%$ of respondents' to whom they sent mobile advertisement and rest of the majority $83 \%$ of respondents are not considered for permission generating that also hampered the effectiveness of the mobile advertising. The study also finds out $53.1 \%$ of respondents experienced that they have got discounts or coupons message through mobile advertising and rest $38.5 \%$ of respondent haven't familiar with it. It also mentioned that $51.5 \%$ of respondents have high involvement with mobile advertising and $48.5 \%$ respondents have moderate or less involvement with mobile advertising. The study also exhibits that only $23.1 \%$ of respondents are often used mobile advertising for their shopping purpose. Mostly 31.5\% of respondents would like to receive mobile advertising in morning and $30 \%$ of respondents at night. $67.7 \%$ of respondents are showing their concern that they want to receive three or more messages in a day.

\subsection{Reliability Analysis}

The study calculated Cronbach Alpha test to find out the internal consistency that displays reliability of various factors of the questionnaire. For the reliability test, data will be considered as reliable when Cronbach Alpha value is exceeding 0.7. Table 3, shows that calculated value of the Cronbach Alpha of the factors is 0.868 that means data is reliable because the pragmatic value is relatively higher than the standard reliable value of Cronbach Alpha.

Table 3. Reliability Statistics

\begin{tabular}{lll}
\hline Cronbach's Alpha & $\begin{array}{l}\text { Cronbach's Alpha Based } \\
\text { on Standardized Items }\end{array}$ & N of Items \\
\hline .868 & .881 & 21 \\
\hline
\end{tabular}

\subsection{Descriptive Statistics of the Study}

The descriptive statistics Table 4, shows that mean and standard deviation value of all the questions which has been designed under Seven (7) Point's Semantic scale considering as values 7-strongly agrees and 1-strongly disagrees feeling on the statement that was given to the respondent. The observed mean value is 4.0769 or more with little value of standard deviations of all statements that experienced the customers' satisfactory level towards the mobile advertising. Overall result justify that respondents are showing multicolored attitude towards the advertising through mobile phone.
Table 4. Descriptive Statistics.

\begin{tabular}{llll}
\hline & Mean & $\begin{array}{l}\text { Std. } \\
\text { Deviation }\end{array}$ & $\begin{array}{l}\text { Analysis } \\
\text { N }\end{array}$ \\
\hline $\begin{array}{l}\text { Enjoy ability \& Entertain ability } \\
\text { of MA }\end{array}$ & 4.0769 & 1.60723 & 130 \\
$\begin{array}{l}\text { Pleasantness of MA } \\
\text { Positive Entertaining Service is }\end{array}$ & 4.4077 & .99375 & 130 \\
positive & 4.6000 & 1.27346 & 130 \\
$\begin{array}{l}\text { MA are Various } \\
\text { Timely Information }\end{array}$ & 4.6154 & 1.00683 & 130 \\
$\begin{array}{l}\text { MA always provide the } \\
\text { information }\end{array}$ & 5.2615 & 1.37843 & 130 \\
$\begin{array}{l}\text { MA keeps me up-to date } \\
\text { I receive exclusive information }\end{array}$ & 5.3077 & 1.34017 & 130 \\
$\begin{array}{l}\text { MA is irritating } \\
\text { MA is almost everywhere }\end{array}$ & 5.0615 & 1.31629 & 130 \\
$\begin{array}{l}\text { I am uncomfortable with } \\
\text { accepting MA }\end{array}$ & 5.1077 & 1.01345 & 130 \\
$\begin{array}{l}\text { Contents in MA are often } \\
\text { annoying. }\end{array}$ & 4.5692 & 1.11326 & 130 \\
$\begin{array}{l}\text { MA is as a reference for } \\
\text { purchasing }\end{array}$ & 5.5308 & .96600 & 130 \\
$\begin{array}{l}\text { MA is credible } \\
\text { I am impressed by MA } \\
\text { Mobile Phone will become an } \\
\text { advertising tool in the future }\end{array}$ & 5.5538 & 1.30034 & 130 \\
$\begin{array}{l}\text { Id accept MA if I was given } \\
\text { financial incentives }\end{array}$ & 4.5154 & 1.22148 & 130 \\
MA provide incentive to me & 5.7308 & 1.23758 & 130 \\
\hline & 4.9000 & 1.02564 & 130 \\
\hline
\end{tabular}

\subsection{Factor Analysis}

Both the Kaiser-Meyer-Olkin (KMO) and Bartlett's test of Sphericity statistics measure sampling adequacy of the study. Bartlett's test of Sphericity value should be considered $(p<0.05)$ for the significance of the factor analysis and KMO value should be considered in the range of 0 to 1 . The Table 5, shows the calculated value of Bartlett's test of Sphericity and KMO measure 0.000 and 0.553 respectively which directly indicates that data collected from the respondents is justified for factor analysis.

Communalities Table 6, Shows that the communalities value is more than 0.737 accepting single variable i.e. I receive exclusive information. It indicates that all the predictors of the study have a significant fraction of the variation which highly contributes to build common factors.

Table 5. KMO and Bartlett's Test.

\begin{tabular}{lll}
\hline Kaiser-Meyer-Olkin Measure of Sampling Adequacy. & $\mathbf{. 5 5 3}$ \\
\hline \multirow{2}{*}{ Bartlett's Test of } & Approx. Chi-Square & 2196.088 \\
Sphericity & Df & 153 \\
& Sig. & .000 \\
\hline
\end{tabular}

Any study can extract factors on Screen plot having more than one (1) Eigen value. Given figure 2. shows that there are six common factors that have the value above from Eigen values 1 . So, the study can be extracted six common factors. 
Table 6. Communalities

\begin{tabular}{lll}
\hline & Initial & Extraction \\
\hline Enjoy ability \& Entertain ability of MA & 1.000 & .823 \\
Pleasantness of MA & 1.000 & .868 \\
Positive Entertaining Service & 1.000 & .829 \\
MA are Various & 1.000 & .818 \\
Timely Information & 1.000 & .736 \\
MA always provide the information & 1.000 & .799 \\
MA keeps me up-to date & 1.000 & .766 \\
I receive exclusive information & 1.000 & .557 \\
MA is irritating & 1.000 & .883 \\
MA is almost everywhere & 1.000 & .823 \\
I am uncomfortable with accepting MA & 1.000 & .805 \\
Contents in MA are often annoying. & 1.000 & .825 \\
MA is as a reference for purchasing. & 1.000 & .885 \\
MA is credible & 1.000 & .843 \\
I am impressed by MA & 1.000 & .737 \\
Mobile Phone will become an advertising tool & 1.000 & .757 \\
in the future & 1.000 & .769 \\
I'd accept MA if I was given financial incentives & 1.000 & .837 \\
MA provide incentive to me & & \\
Extraction Method: Principal Component Analysis. & & \\
\hline
\end{tabular}

For supporting to the outcome, an exploratory principal component analysis is done through SPSS 20 version. Table 7 , shows the total variance of the various components. These components are referred as principal components which have Eigen value higher than 1. It is quite clear that there are six components that have Eigen value more than 1 which complains $79.776 \%$ of total Varimax rotation for the rotated component matrix. This method helps in minimization of number of variables that are having high loadings on each factor and provides the factors underlying for attitudes towards mobile advertising. As per the given table all variables can be categorized into six factors.

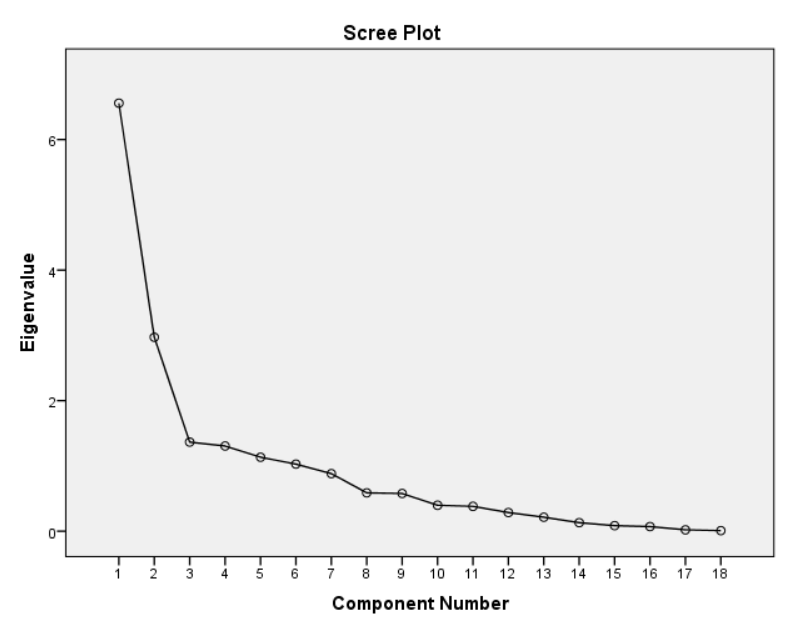

Figure 2. Screen Plot.

Rotated Component Matrix Table 8, Varimax rotation was keep fit for the rotated component matrix. As per the following table all variables can be categorized into six: factor 1 , factor 2, factor 3, factor 4, factor 5 and factor 6 . Where, Factor 1 includes variables i.e. enjoy ability \& entertain ability of MA, pleasantness of MA, MA are various, $\mathrm{MA}$ is irritating, MA is as a reference for purchasing, MA is credible, I am impressed by MA, mobile phone will become an advertising tool in the future, I'd accept MA if I was given financial incentives, and MA provide incentive to me. Factor 2 includes variables i.e. uncomfortable with accepting MA and Contents in MA are often annoying. Factor 3 includes only one variable named timely information.

Table 7. Total Variance Explained.

\begin{tabular}{|c|c|c|c|c|c|c|c|c|c|}
\hline \multirow{2}{*}{ Components } & \multicolumn{3}{|c|}{ Initial Eigenvalues } & \multicolumn{3}{|c|}{ Extraction Sums of Squared Loadings } & \multicolumn{3}{|c|}{ Rotation Sums of Squared Loadings } \\
\hline & Total & $\%$ of Variance & Cumulative \% & Total & $\%$ of Variance & Cumulative \% & Total & $\%$ of Variance & Cumulative \% \\
\hline 1 & 6.558 & 36.432 & 36.432 & 6.558 & 36.432 & 36.432 & 5.944 & 33.021 & 33.021 \\
\hline 2 & 2.971 & 16.507 & 52.938 & 2.971 & 16.507 & 52.938 & 2.882 & 16.013 & 49.034 \\
\hline 3 & 1.365 & 7.585 & 60.523 & 1.365 & 7.585 & 60.523 & 1.547 & 8.595 & 57.629 \\
\hline 4 & 1.305 & 7.248 & 67.771 & 1.305 & 7.248 & 67.771 & 1.476 & 8.199 & 65.828 \\
\hline 5 & 1.133 & 6.296 & 74.066 & 1.133 & 6.296 & 74.066 & 1.322 & 7.345 & 73.173 \\
\hline 6 & 1.028 & 5.709 & 79.776 & 1.028 & 5.709 & 79.776 & 1.189 & 6.603 & 79.776 \\
\hline 7 & .882 & 4.898 & 84.674 & & & & & & \\
\hline 8 & .588 & 3.267 & 87.940 & & & & & & \\
\hline 9 & .577 & 3.208 & 91.148 & & & & & & \\
\hline 10 & .397 & 2.208 & 93.356 & & & & & & \\
\hline 11 & .381 & 2.115 & 95.470 & & & & & & \\
\hline 12 & .286 & 1.587 & 97.058 & & & & & & \\
\hline 13 & .214 & 1.187 & 98.245 & & & & & & \\
\hline 14 & .131 & .727 & 98.972 & & & & & & \\
\hline 15 & .084 & .468 & 99.440 & & & & & & \\
\hline 16 & .071 & .396 & 99.836 & & & & & & \\
\hline 17 & .021 & .117 & 99.953 & & & & & & \\
\hline 18 & .008 & .047 & 100.00 & & & & & & \\
\hline \multicolumn{10}{|c|}{ Extraction Method: Principal Component Analysis. } \\
\hline
\end{tabular}


Table 8. Rotated Component Matrix ${ }^{a}$

\begin{tabular}{|c|c|c|c|c|c|c|}
\hline & \multicolumn{6}{|c|}{ Components } \\
\hline & 1 & 2 & 3 & 4 & 5 & 6 \\
\hline Enjoy ability \& Entertainment ability of MA & .789 & & & & & \\
\hline Pleasantness of MA & .702 & & & & & \\
\hline Positive Entertaining Service & & & & .668 & & \\
\hline MA are Various & .795 & & & & & \\
\hline Timely Information & & & .848 & & & \\
\hline MA always provide the right information & & & & & .887 & \\
\hline MA keeps me up-to date & & & & & & .839 \\
\hline I receive exclusive information & & & & & .279 & \\
\hline MA is irritating & .656 & & & & & \\
\hline MA is almost everywhere & & & & .764 & & \\
\hline I am uncomfortable with accepting MA & & .810 & & & & \\
\hline Contents in MA are often annoying. & & .878 & & & & \\
\hline MA is as a reference for purchasing. & .911 & & & & & \\
\hline MA is credible & .798 & & & & & \\
\hline I am impressed by MA & .840 & & & & & \\
\hline Mobile Phone will become an advertising tool in the future & .783 & & & & & \\
\hline I'd accept MA if I was given financial incentives & .401 & & & & & \\
\hline MA provide incentive to me & .650 & & & & & \\
\hline Extraction Method: Principal Component Analysis. & & & & & & \\
\hline a. Rotation converged in 8 iterations. & & & & & & \\
\hline
\end{tabular}

Factor 4 includes variables like positive Entertaining Service and MA is almost positive in everywhere. Factor 5 includes variables i.e. MA always provides the information and I receive exclusive information. Factor 6 includes only one variable named MA keeps me up-to date. For the further study, those given six factors can be used to find out better result.

\subsection{Regression Analysis}

Table 9. Model Summary.

\begin{tabular}{lllll}
\hline $\begin{array}{l}\text { Mode } \\
\mathbf{l}\end{array}$ & $\mathbf{R}$ & R Square & $\begin{array}{l}\text { Adjusted R } \\
\text { Square }\end{array}$ & $\begin{array}{l}\text { Std. Error of } \\
\text { the Estimate }\end{array}$ \\
\hline \multicolumn{4}{c}{$\begin{array}{l}.843 \mathrm{a} \\
\text { a. Predictors: (Constant), Incentive, Informativeness, Irritation, Credibility, } \\
\text { Entertainment }\end{array}$} \\
\hline
\end{tabular}

Adjusted $\mathrm{R}^{2}$, the coefficient of determination, implies that "customer attitude towards the mobile advertising" is explained $69.8 \%$ by the independent variables i.e. Incentive, Informativeness, Irritation, Credibility, Entertainment.

Table 10. ANOVA ${ }^{a}$.

\begin{tabular}{llllll}
\hline Model & $\begin{array}{l}\text { Sum of } \\
\text { Squares }\end{array}$ & Df & $\begin{array}{l}\text { Mean } \\
\text { Square }\end{array}$ & F & Sig. \\
\hline Regression & 71.932 & 5 & 14.386 & 60.672 & $.000 \mathrm{~b}$ \\
Residual & 29.402 & 124 & .237 & & \\
Total & 101.334 & 129 & & & \\
a. Dependent Variable: Attitude & & & & \\
b. Predictors: (Constant), Incentive, Informativeness, Irritation, Credibility, \\
Entertainment
\end{tabular}

As per the ANOVA Table 10, P-value (0.000) is less than 0.05; the alternative hypothesis is accepted at the $95 \%$ level of confidence. This implies that the model is significant. That means incentive, informativeness, irritation, credibility, entertainment can significantly explained customer attitude towards the mobile advertising.

Table 11. Coefficients ${ }^{a}$.

\begin{tabular}{llllll}
\hline \multirow{2}{*}{ Model } & \multicolumn{2}{l}{$\begin{array}{l}\text { Unstandardized } \\
\text { Coefficients }\end{array}$} & $\begin{array}{l}\text { Standardized } \\
\text { Coefficients }\end{array}$ & T & Sig. \\
\cline { 2 - 4 } & $\mathbf{B}$ & $\begin{array}{l}\text { Std. } \\
\text { Error }\end{array}$ & Beta & & \\
\hline (Constant) & .920 & .526 & & 1.748 & .083 \\
Entertainment & .213 & .088 & .230 & 2.424 & .017 \\
Informativeness & -.131 & .065 & -.098 & -2.010 & .047 \\
Irritation & .187 & .076 & .166 & 2.461 & .015 \\
Credibility & .384 & .079 & .438 & 4.845 & .000 \\
Incentive & .168 & .063 & .211 & 2.684 & .008 \\
a. Dependent Variable: Attitude & & & \\
\hline
\end{tabular}

The one above coefficients Table 11, indicates that there is a strong significance relationship between credibility and incentive with consumer mobile advertising attitude and entertainment also affects consumer attitude. This table also indicates that Entertainment, Informativeness, Credibility and Incentive have a positive influence on consumer attitude as the sig. values are $(0.017),(0.047),(0.000)$, and $(0.008)$ while those are less than significance level of 0.05 . The supposed irritation has sig. Value (0.015) and it's also less than standard value 0.05 . So irritation has a strong effect on the mobile advertising attitude of the customer.

\subsection{Test of Hypothesis}

Hypothesis (H1): The alternative hypothesis, H1, entertainment of advertising has a positive significant influence on customer's attitude towards mobile advertising in Bangladesh, proves as per the evidence that entertainments' 
$\mathrm{p}$-value is 0.017 which is less than the value of 0.05 .

Hypothesis (H2): The alternative hypothesis, $\mathrm{H} 2$, informativeness of advertising has a positive significant influence on customer's attitude towards mobile advertising in Bangladesh, proves as per the evidence that entertainments' p-value is 0.047 which is less than the value of 0.05 .

Hypothesis (H3): The alternative hypothesis, $\mathrm{H} 3$, irritation of advertising has a significant negative influence on customer's attitude towards mobile advertising in Bangladesh, proves as per the evidence that entertainments' $p$-value is 0.015 which is less than the value of 0.05 .

Hypothesis (H4): The alternative hypothesis, H4, credibility of advertising has a positive significant influence on customer's attitude towards mobile advertising in Bangladesh, proves as per the evidence that entertainments' $\mathrm{p}$-value is 0.000 which is less than the value of 0.05 .

Hypothesis (H5): The alternative hypothesis, $\mathrm{H} 5$, incentive of advertising has a positive significant influence on customer's attitude towards mobile advertising in Bangladesh, proves as per the evidence that entertainments' $p$-value is 0.000 which is less than the value of 0.05 .

All these results justify that entertainment; informativeness; credibility; incentive and irritation have a reliant effect on customer's attitude towards mobile advertising in Bangladesh.

\section{Conclusion and Recommendation}

Mobile advertising is the best personal communication channel that involves sender and receiver for communicating directly to each other. As a result, a growing number of companies of Bangladesh are adopting the concept of Mobile Advertising (MA) that has a good message consistence and greater impact on the company's sales. Not only that mobile advertising also has a good reach frequency and impact different exposure to the target audience. The study has been explored to examine the customer's attitude towards mobile advertising in Bangladesh. It also verified the direct influence of entertainment, informativeness, irritation, credibility and incentive on consumer attitude towards mobile advertising. On the conceptual framework of the study, entertainment, informativeness, credibility and incentive have shown direct positive and significant influence on consumer attitude toward mobile advertising. Here, only one predictor named irritation has shown direct negative and significant influence on consumer attitude towards mobile advertising. The study has also found some findings on different perspectives, including; the expected time of receiving mobile advertising, the number of advertising that a customer wants to receive in a day, taking permission before sending advertising those can make easy to take proper advertising and communication related decision by the marketer. Many companies in Bangladesh can use mobile advertising to stimulate about their product and services. Here the advertiser can create various types of appeals in the customer's mind that will help to pursue. So the outcomes of this effort will be very much helpful to designing on the integrating marketing communication (IMC) or promotional mix because mobile advertising is the most cost effective and new tools for the promoter. Advertising content, format and structure must be accurate, attractive and accepted by the target audience or receiver of mobile advertisers. Those clarified mobile advertising and communication decisions help to improve advertising efficiency resulting with high sales volume and strong customer relationship. For the further research, researcher can improve the number of respondents with their demographic variation.

\section{Appendix}

\begin{tabular}{|c|c|c|}
\hline Variables & Measures & References \\
\hline Entertainment & $\begin{array}{l}\text { I feel that receiving mobile advertisements are enjoyable and entertaining } \\
\text { I feel that receiving mobile advertisements are pleasant. } \\
\text { I find entertainment services (video, game, images,) positive } \\
\text { I feel that the form-designs of mobile advertisements are various. } \\
\text { I feel that mobile advertising is a good source for timely information. }\end{array}$ & \\
\hline Informativeness & $\begin{array}{l}\text { Mobile advertisements always provide the information I need. } \\
\text { Mobile advertising always can help me keep up-to date about products or service. } \\
\text { Through advertising via mobile phone, I receive exclusive information }\end{array}$ & $\begin{array}{l}\text { Tsang, M. M., Ho, S. C., and Liang, T. P. } \\
\text { (2004), David, J. J. X. (2006), Chowdhury, }\end{array}$ \\
\hline Irritation & $\begin{array}{l}\text { I feel that mobile advertising is irritating. } \\
\text { I feel that mobile advertisements are almost everywhere. } \\
\text { I am comfortable with accepting advertising messages on my mobile phone } \\
\text { Contents of mobile advertisements are often annoying. }\end{array}$ & $\begin{array}{l}\text { H. K. et al (2006), Shura, M., and Elsayed, } \\
\text { E. A. (2012), Liu, W. L., \& Jang, H. Y. }\end{array}$ \\
\hline Credibility & $\begin{array}{l}\text { I use mobile advertising as a reference for purchasing. } \\
\text { I think the content provided by mobile advertising is credible. } \\
\text { I am impressed by the mobile advertisements. } \\
\text { I think it is inevitable that mobile phones will become an advertising tool in the future }\end{array}$ & \\
\hline Incentive & $\begin{array}{l}\text { I would accept mobile advertising messages if I was given financial incentives } \\
\text { I am impressed by the mobile advertisements if they will provide incentive to me }\end{array}$ & $\begin{array}{l}\text { Tsang, M. M., Ho, S. C., and Liang, T. P. } \\
\text { (2004), }\end{array}$ \\
\hline Attitude & $\begin{array}{l}\text { I am satisfied with mobile advertising. } \\
\text { I have positive perception about mobile advertising } \\
\text { I think mobile Advertising which is better than the traditional ways of advertising. }\end{array}$ & $\begin{array}{l}\text { Tsang, M. M., Ho, S. C., and Liang, T. P. } \\
\text { (2004), David, J. J. X. (2006), Kim, C. } \\
\text { J.(2009), Shura, M., and Elsayed, E. A. } \\
\text { (2012), Liu, W. L., \& Jang, H. Y. }\end{array}$ \\
\hline
\end{tabular}




\section{References}

[1] Aaker, D. A., \& Bruzzone, D. E. (1985). Causes of irritation in advertising. The journal of marketing, 47-57.

[2] Ajzen, I., \& Fishbein, M. (1980). Understanding attitudes and predicting social behaviour.

[3] Alhrezat, R. S. (2013). Factors affecting consumer's attitude toward mobile marketing. European Journal of Business and Management, 5(8), 125-135.

[4] Altuna, O. K., \& Konuk, F. A. (2009). Understanding consumer attitudes toward mobile advertising and its impact on consumers behavioral intentions: A crossmarket comparison of united states and turkish consumers. International Journal of Mobile Marketing, 4(2).

[5] Barnes, S. J., \& Scornavacca, E. (2004). Mobile marketing: the role of permission and acceptance. International Journal of Mobile Communications, 2(2), 128-139.

[6] Barnes, S. J., \& Scornavacca, E. (2008). Uncovering patterns in mobile advertising opt-in behaviour: a decision hierarchy approach. International Journal of Mobile Communications, 6(4), 405-416.

[7] Bauer, H. H., Barnes, S. J., Reichardt, T., \& Neumann, M. M. (2005). Driving consumer acceptance of mobile marketing: a theoretical framework and empirical study. Journal of electronic commerce research, 6(3), 181-192.

[8] Bauer, R. A., \& Greyser, S. A. (1968). Advertising in America: The Consumer View (Harvard University, Graduate School of Business Administration, Division of Research, Boston, MA.).

[9] BOSE, T. K., NAHID, A. A., Islam, M. T., \& Saha, R. K. (2010). SMS Advertising and Its prospects in Bangladesh. Journal of Theoretical \& Applied Information Technology, 11.

[10] Brackett, L. K., \& Carr, B. N. (2001). Cyberspace advertising vs. other media: Consumer vs. mature student attitudes. Journal of advertising research, 41(5), 23-32.

[11] Carroll, A., Barnes, S. J., Scornavacca, E., \& Fletcher, K. (2007). Consumer perceptions and attitudes towards SMS advertising: recent evidence from New Zealand. International Journal of Advertising, 26(1), 79-98.

[12] Choi, S. M., \& Rifon, N. J. (2002). Antecedents and consequences of web advertising credibility: A study of consumer response to banner ads. Journal of Interactive Advertising, 3(1), 12-24.

[13] Chowdhury, H. K., Parvin, N., Weitenberner, C., \& Becker, M. (2010). Consumer attitude toward mobile advertising in an emerging market: An empirical study. Marketing, 12(2), 206216.

[14] Daugherty, T., Logan, K., Chu, S. C., \& Huang, S. C. (2008). Understanding consumer perception of advertising: A theoretical framework of attitude and confidence. In American Academy of Advertising. pp. 308-313.

[15] Dawar, S., \& Kothari., A. (2013). A study of consumer attitude towards advertising through mobile phones. Tirpude's National Journal of Business Research, 4(2).
[16] Dickinger, A., Haghirian, P., Murphy, J., \& Scharl, A. (2004, January). An investigation and conceptual model of SMS marketing. In System Sciences, 2004. Proceedings of the 37th Annual Hawaii International Conference on (pp. 10-pp). IEEE.

[17] Ducoffe, R. H. (1996). Advertising value and advertising on the web. Journal of advertising research, 36(5), 21-35.

[18] Ducoffe, R. H. (1995). How consumers assess the value of advertising. Journal of Current Issues \& Research in Advertising, 17(1), 1-18

[19] Goldsmith, R. E., Lafferty, B. A., \& Newell, S. J. (2000). The impact of corporate credibility and celebrity credibility on consumer reaction to advertisements and brands. Journal of Advertising, 29(3), 43-54.

[20] Grant, I., \& O'Donohoe, S. (2007). Why young consumers are not open to mobile marketing communication. International Journal of Advertising, 26(2), 223-246.

[21] Haghirian, P., \& Dickinger, A. (2004). Identifying success factors of mobile marketing. ACR Asia-Pacific 2004 (Association of Consumer Research).

[22] Haghirian, P., \& Inoue, A. (2006). An advanced model of consumer attitudes toward advertising on the mobile internet. International Journal of Mobile Communications, 5(1), 48-67.

[23] Haider, I (2012). Prioritization of Factors Affecting Consumer attitude towards Mobile Advertisement: A Study of Pakistani Youth.

[24] Hoffman, D. L., \& Novak, T. P. (1996). Marketing in hypermedia computer-mediated environments: conceptual foundations. The Journal of Marketing, 50-68.

[25] Kalakota, R., Robinson, M., \& Kalakota, D. R. (2002). MBusiness: the race to mobility (pp. 3-4). New York, NY: McGraw-Hill.

[26] Katterbach, W. (2002). Die SMS - VerKaufer. Impulse, February Ist, 6.

[27] Kotler, P. (2006). Marketing management: A south Asian perspective. Pearson Education India.

[28] Kotler, P., \& Armstrong, G. (2010). Principles of marketing. Pearson Education.

[29] Le, T. D., \& Nguyen, B. T. H. (2014). Attitudes toward mobile advertising: A study of mobile web display and mobile APP display advertising.

[30] Luxton, S., Mahmood, U., \& Ferraro, C. (2009). Mobile phone marketing: challenges and perceived attitudes. In Australian and New Zealand Marketing Academy (ANZMAC) Conference 2009 (Mike Ewing and Felix Mavondo 30 November 2009 to 2 December 2009) (pp. 1-11).

[31] MacKenzie, S. B., \& Lutz, R. J. (1989). An empirical examination of the structural antecedents of attitude toward the ad in an advertising pretesting context. The Journal of Marketing, 48-65.

[32] Mobile Advertising Definition Investopedia $\mathrm{http}: / /$ www.investopedia.com/terms $/ \mathrm{m} / \mathrm{mobileadvertising.asp \#}$ ixzz3keCAhd4s.

[33] Mobithinking. (2013, 22 January). Blog: Mobile advertising statistics 2013. Retrieved from Mobithinking website: http://mobithinking.com/blog/mobile-advertisingstatistics-2013. 
[34] Okazaki, S. (2005). External search, content credibility and intrinsic gratifiers influencing attitude toward wireless ads. Asia Pacific Advances in Consumer Research, 6(7), 5-12.

[35] Punyatoya, P., \& Durgesh, P (2011). Attitude towards Mobile Advertising: A Study of Indian Consumers.

[36] Rip, A. and Kemp, R. (1998). 'Technological Change', in S. Rayner and E. L. Malone (eds) Human Choice and Climate Change. Columbus, OH: Battelle Press.

[37] Rittippant, N., Witthayawarakul, J., Limpiti, P., \& Lertdejdecha, N. (2009). Consumers' perception of the effectiveness of Short Message Service (SMS) and Multimedia Message Service (MMS) as marketing tools. Proceedings of World Academy of Science: Engineering \& Technology, 53, p815.

[38] Rohm, A. J., Gao, T. T., Sultan, F., \& Pagani, M. (2012). Brand in the hand: A cross-market investigation of consumer acceptance of mobile marketing. Business Horizons, 55(5), 485-493.

[39] Saeed, R., Lodhi, R. N., Khan, M. Z., Akbar, A., Mahmood, Z., \& Ahmad, M. (2013). Consumer Attitude Towards Advertisement via Mobile. World Applied Sciences Journal, 26(5), 672-676.

[40] Scharl, A., Dickinger, A., \& Murphy, J. (2005). Diffusion and success factors of mobile marketing. Electronic commerce research and applications, 4(2), 159-173.

[41] Schiffman, L. G., Hansen, H., \& Kanuk, L. L. (2008). Consumer behaviour: A European outlook. Pearson Education.

[42] Shavitt, S., Lowrey, P., \& Haefner, J. (1998). Public attitudes toward advertising: More favorable than you might think. Journal of advertising research, 38(4), 7-22.
[43] Stewart, D. W., \& Pavlou, P. A. (2002). From consumer response to active consumer: Measuring the effectiveness of interactive media. Journal of the Academy of Marketing Science, 30(4), 376-396.

[44] Sultan, F., \& Rohm, A. (2005). The coming era of" brand in the hand" marketing. MIT Sloan Management Review, 47(1), 83.

[45] Tedeschi, B. (2007). Reaching more customers with a simple text message. The New York Times, 16 July, http://www.nytimes.com/2007/07/16/business/media/16ecom. html, Retrieved from $16^{\text {th }}$ July, 2009.

[46] Tsang, M. M., Ho, S. C., \& Liang, T. P. (2004). Consumer attitudes toward mobile advertising: An empirical study. International Journal of Electronic Commerce, 8(3), 65-78.

[47] Varshney, U. (2003). Location management for mobile commerce applications in wireless internet environment. $A C M$ Transactions on Internet Technology (TOIT), 3(3), 236-255.

[48] Wiedemann, D. G., Palka, W., \& Pousttchi, K. (2008, July). Understanding the determinants of mobile viral effectstowards a grounded theory of mobile viral marketing. In Mobile Business, 2008. ICMB'08. 7th International Conference on (pp. 323-333). IEEE.

[49] Xu, D. J. (2006). The influence of personalization in affecting consumer attitudes toward mobile advertising in China. Journal of Computer Information Systems, 47(2), 9.

[50] Zabadi, A. M. A., Shura, M., \& Elsayed, E. A. (2012). Consumer attitudes toward SMS advertising among Jordanian users. International Journal of Marketing Studies, 4(1), p77.

[51] Zanton,E.(1981). Public attitudes toward advertising, in Hunt, K. (ed.).Advertising in a NewAge , Proeceedings of the Annual Conference for the American Academy of Advertising, Brigham Young University Press, Provo, pp. 141 - 146. 